\title{
The Forgotten Ones: How Rural Teachers in Mexico are Facing the COVID-19 Pandemic
}

\author{
Brenda Cecilia Padilla Rodríguez \\ Universidad Autónoma de Nuevo León \\ Alejandro Armellini \\ University of Portsmouth, United Kingdom \\ John Traxler \\ University of Wolverhampton, United Kingdom
}

\begin{abstract}
The COVID-19 global pandemic resulted in the cancellation of face-to-face classes in Mexico, as it did across the world. This paper focuses on the experiences of 75 rural teachers in Mexico, who represent a minority in a country where approximately $80 \%$ of the population lives in urban areas. An online survey was administered to participants, who taught in a variety of schools, including K-12 and university settings. These participants shared how they changed their teaching practice, the challenges they faced, and the support they required. The digital divide represented a key challenge for both teachers and their students. In the face of inconsistent, unclear, or non-existent government support, most rural teachers showed commitment, resilience, and resourcefulness. They took control of, and responsibility for, their professional development by seeking ways to fill gaps in their knowledge and continue supporting their learners. Recommendations for institutional authorities and policy makers are discussed.
\end{abstract}

Keywords: Rural teachers, pandemic, COVID-19, educational changes, teaching practices, staff development, resourcefulness, emergency remote teaching, digital learning

Padilla Rodríguez, B.C., Armellini, A., \& Traxler, J. (2021). The forgotten ones: How rural teachers in Mexico are facing the COVID-19 pandemic. Online Learning, 25(1), 253268. https://doi.org/10.24059/olj.v25i1.2453 


\section{The Forgotten Ones: How Rural Teachers in Mexico are Facing the COVID-19 Pandemic}

The COVID-19 pandemic forced universities and schools worldwide to cancel face-to-face activities amidst fears of contagion. Governments and institutions turned to online learning as a way of ensuring continued access to education (Bao, 2020; Dube, 2020; Mohammed et al., 2020). Teachers in all sectors had to transform their courses on short notice, with insufficient time to develop robust pedagogic redesigns or acquire the skills needed to continue their practice online. This shift, which derives from a health crisis and is expected to be temporary, is known as emergency remote teaching (Hodges et al., 2020).

The emergency transition to online learning during the COVID-19 crisis was complex and fraught with the risk of failure (World Bank, 2020). Despite international recommendations to provide professional development, training, and guidance to instructors, many educators were forced to rely on informal, self-directed learning to learn about online teaching as they were teaching online (Omadan, 2020; Trust \& Whalen, World Bank, 2020). Some felt overwhelmed and unprepared for the task, worried about the potential negative consequences of substituting digital activities for their regular face-to-face activities, or struggled to help students who may lack the necessary self-discipline or an adequate learning environment at home (Bao, 2020; Martin et al., 2019; Sintema, 2020; Trust \& Whalen, 2020). In order to cope with such challenges, some teachers reduced or removed learning outcomes, or switched to less active and more instructorcentred approaches (Barton, 2020).

The challenges of emergency remote teaching may have particularly adverse impacts on communities that are distant from the urban and economic mainstream, and thus may have less access to and understanding of global educational resources (Traxler et al., in press). This paper reports on the experiences of rural Mexican teachers during the emergency transition to remote learning at the outset of the COVID-19 pandemic by exploring the changes in their teaching practice, the difficulties they faced and the support they required.

\section{Rural Communities and Education During the COVID-19 Pandemic}

Even before the COVID-19 pandemic, rural communities across the world faced distinct challenges in terms of education. These difficulties are often rooted in poverty, which translates into a lack of resources and an inadequate infrastructure (Çiftçi \& Cin, 2018; Dube, 2020; Kapasia et al., 2020; Omodan, 2020). Rural teachers are likely to have limited engagement in on-the-job learning (Hallinger \& Liu, 2016). Moreover, textbooks and other teaching materials created at a state or national level may reflect an insufficient understanding of rural contexts, which may result in irrelevant curricula (Çiftçi \& Cin, 2018). Rural students have lower completion rates than nonrural students (Wells et al., 2019).

Challenges already present in rural communities before COVID-19 were exacerbated during lockdown. Many rural learners have had to discontinue their studies. They may lack electricity, internet connectivity, suitable electronic devices or qualified teachers who can guide them with online learning. They may not be able to attend online synchronous classes or join asynchronous sessions. While session recordings and other self-directed materials help, they do not offer opportunities to interact with teachers and students. Such constraints are likely to take a toll on academic performance (Kapasia et al., 2020; Mohmmed et al., 2020; Sintema, 2020). 
Access to the Internet is a critical issue for teachers and students in rural and remote areas. While the widespread use of mobile devices has enabled many people to connect, online service can be very expensive in rural areas of Mexico. This situation worsens when people are unemployed and have less income available to allocate to educational purposes (Dube, 2020; Kapasia et al., 2020). Some villages have public libraries or internet cafés where students can go online. However, COVID-19 has impeded access to them. Even if people were allowed to visit these facilities, it is likely that they would soon be over capacity due to the increased demand (Dube, 2020; Omodan, 2020).

Inequalities between rural and nonrural areas are clear. Those who are already competent in the use of learning technologies, have access to broadband Internet-connected devices, and family support are best placed to have a successful online or digital learning experience (World Bank, 2020). Online learning thus excludes those in deprived communities, favours urban learners, and widens the rural-nonrural gap in terms of the educational experience (Dube, 2020; Omodan, 2020). During COVID-19, other effects have been reported anecdotally, such as competition for educational bandwidth versus recreation bandwidth in large families with limited online capacity and the challenges of home-schooling for key-worker families (Traxler et al., in press)

In regions with no broadband Internet access, educational radio and television programmes enable education in Mexico and elsewhere. While evidence of their impact on learning outcomes, engagement, and motivation is scarce, these media represent viable options that can be set up on relatively short notice, particularly if they are adaptations of lecture-based materials (World Bank, 2020). Unfortunately, their content is standard and difficult to adapt to specific regional or rural areas. Yet, a consideration of culture and context is paramount to ensure the value of any educational intervention during the COVID-19 pandemic (Traxler et al., in press).

\section{The Rural Scenario in Mexico}

In Mexico, education is mandatory for students from age three to approximately eighteen years. Schools around the country share a common educational curriculum which establishes essential content and learning objectives. Teachers are free to expand on the core topics to address contextual needs. However, they are required to follow the general guidelines (SEP, 2016) which are, by default, designed for urban institutions. Teachers in rural communities are expected to adjust as required and ultimately comply with such guidance.

Across Mexico, academic achievement at all levels faces substantial challenges. According to the Programme for International Student Assessment (PISA), Mexican students score lower than the OECD average in reading, mathematics, and science. Many of them $(35 \%$; OECD average: $13 \%$ ) do not achieve the minimum level of proficiency in all three subjects. Their socio-economic status is a strong predictor of their performance (OECD, 2019). The negative impact of poverty is particularly challenging for students in rural areas, who represent about $20 \%$ of all students (INEE, 2019).

Life conditions in rural areas across Mexico are usually precarious, characterised by marginalisation and poverty (INEE, 2006). Rural residents have lower levels of educational achievement than those in urban areas, and many do not complete their basic education (INEE, 2019). As rural state schools receive fewer and inferior quality resources than urban institutions, they are less likely to attract and retain well-prepared, experienced teachers. The Mexican government has failed to provide an adequate infrastructure for rural schools (Juárez Bolaños \& Rodríguez Solera, 2016), and indeed has stated that providing small rural areas with fully 
functioning educational centres is economically unfeasible (INEE, 2006, p. 78). In line with these challenges, a large study with Mexican teachers $(n=43,845)$ found that rural residents are more depressed than their urban counterparts (Soria-Saucedo et al., 2018).

Residents in rural Mexican areas have slowly become more connected to the Internet. According to Mexico's National Survey on the Availability and Use of Information Technologies at Home (INEGI, 2020), between 2017 and 2019, the proportion of rural residents using the Internet increased from $39 \%$ to $48 \%$. Mobile phones are the most prevalent technology in the country, with $59 \%$ of rural residents having access to one. While these figures represent progress, they still lag far behind the same metrics in urban areas, where $77 \%$ of residents have access to the Internet and $80 \%$ have a mobile phone.

For decades, rural students without Internet access have relied on telesecundarias, or programmes for 12-15-year-old students who have completed their primary education. Their classes consist of a 15-minute television programme, which can be accessed via satellite TV or Internet, plus 35 minutes of face-to-face work with a teacher. This initiative, which represents the only option for many students who live in rural or remote areas, currently has more than 18,000 centres where more than a million learners can continue their education (Coordinación General @ prende.mx, 2020). However, telesecundaria teachers have reported lacking the required equipment, knowledge, and training to adequately support students. Moreover, their students' digital literacy is limited. This situation can be demotivating for educators who are forced to teach what they can with whatever they have available, even if they know students will not achieve the learning outcomes. Some teachers "go the extra mile" and even lend their own devices to students (Ramos Ramón \& Frías López, 2019).

To ensure access to education during the COVID-19 lockdown, which started in midMarch 2020, the Mexican government launched the Aprende en Casa (Learn at Home) programme. This initiative uses several channels to deliver educational content, including Internet, television, and radio. Some materials are available in 15 indigenous languages (SEP, 2020a, 2020b). However, teachers from Oaxaca, a state with a high level of marginalisation (Conapo, 2016) and numerous rural communities, have publicly complained that this initiative does not guarantee access and ignores the lack of Internet and electricity in certain areas of the country. Oaxacan teachers claim the Aprende en Casa strategy is not contextualised to the region's social conditions, marginalisation, extreme poverty, and digital divides. They consider it an attack on children's right to education (CNTE Section XXII, 2020).

Since the majority of Mexico's population lives in urban areas, large-scale quantitative studies usually drown the voices of rural residents. This paper aims to fill this gap by reporting on the perspectives of rural teachers. Drawing from a larger project, eduCOVID-19, which aims to assess how the current COVID-19 pandemic has changed teaching practices around the world, this study considers the following research questions:

1. What are the main changes to teaching practices during the COVID-19 pandemic?

2. What challenges do rural teachers face?

3. What are their main support needs? 


\section{Methods}

\section{Participants}

A nonprobability, convenience sample of 75 educators participated in this study. They all reported living in a rural area, mostly in San Luis Potosi. At least one reported residing in an ejido, a small village whose central activity is farming under a government-supported system. A rural community is traditionally one with under 2,500 residents. However, in highly dispersed towns with larger populations (up to 15,000 people), living conditions can closely resemble the rural environment and can be considered rural (OECD, 2007). In this study, respondents' assessment was the single indicator to determine whether their living and working context was rural or not.

Almost half of the respondents (47\%) were full-time teachers, and 37\% were hourly-paid employees. Respondents taught at different levels (see Table 1), commonly at public institutions (79\%). Their class sizes varied widely, ranging from 5 to 80 students per group, with a mean class size of 23.7 and a median of 22 .

\section{Table 1}

Educational Level Taught by Participants

\begin{tabular}{|c|c|c|c|}
\hline Educational Level & Students' Ages & Frequency $(n=75)$ & Percentage \\
\hline Pre-school & $3-6$ & 18 & $24 \%$ \\
\hline Primary school & $6-12$ & 23 & $31 \%$ \\
\hline Secondary school & $12-15$ & 12 & $16 \%$ \\
\hline Baccalaureate & $15-18$ & 1 & $1 \%$ \\
\hline University & $18+$ & 16 & $21 \%$ \\
\hline $\begin{array}{l}\text { Other types of schools: technical, } \\
\text { languages, special needs, non- } \\
\text { curricular arts, or sports }\end{array}$ & Any & 5 & $7 \%$ \\
\hline
\end{tabular}

\section{Instrument}

An online survey delivered via Google Forms helped obtain information on three main areas:

1. Main changes to teaching practices during the COVID-19 pandemic

2. Challenges faced

3. Support available or required 
It included closed and open questions. It started with an informed consent section and ended with the opportunity to provide additional comments. An online instrument may seem a counterintuitive approach to collect responses from people in areas with limited access to the Internet. However, it was the only available option during lockdown.

\section{Procedure}

Several strategies were deployed to recruit participants. The lead researcher contacted local teacher organisations. She posted the link to the survey on social media (Facebook groups, Twitter, and LinkedIn) with an open invitation to respond and share it. She also spoke to friends and colleagues in Oaxaca and San Luis Potosi (states with a high number of rural residents; Ávila, 2012) who could reach out to potential respondents. This was particularly useful, as it enabled the research team to contact hard-to-reach participants and to ensure that they could access the instrument.

Data collection lasted six weeks, from May 1st to June $12^{\text {th }}$, 2020. The researchers triangulated quantitative and qualitative data to obtain a comprehensive view of the experiences of rural teachers (Salkin, 2010). They obtained frequencies and percentages from closed questions. They also conducted an inductive analysis on open questions, aiming to identify salient themes and common patterns. They then created a coding book for each of the three main open questions (see sample codes in Table 2), including a description and an example of each code.

\section{Table 2}

Sample Codes Used

\section{What is the main CHANGE that you have identified in your own teaching practices as a result of the COVID-19 pandemic?}

\begin{tabular}{|c|c|c|}
\hline Code & Description & Example \\
\hline Technology & $\begin{array}{l}\text { Incorporating digital tools or } \\
\text { resources into regular teaching } \\
\text { practices }\end{array}$ & $\begin{array}{l}\text { "Use of virtual classroom or } \\
\text { platform" }\end{array}$ \\
\hline Adaptation & $\begin{array}{l}\text { Modifying learning content or } \\
\text { activities to facilitate delivery at a } \\
\text { distance }\end{array}$ & $\begin{array}{l}\text { "I modified my teaching practice, } \\
\text { catering my plan to students' } \\
\text { needs" }\end{array}$ \\
\hline \multicolumn{3}{|c|}{$\begin{array}{l}\text { What is the main CHALLENGE you are facing to continue your teaching practice } \\
\text { during COVID-19? }\end{array}$} \\
\hline Code & Description & Example \\
\hline Access & $\begin{array}{l}\text { Lack of internet connection, } \\
\text { phone network or electronic } \\
\text { devices }\end{array}$ & $\begin{array}{l}\text { "There is no internet in our } \\
\text { communities" }\end{array}$ \\
\hline Communication & $\begin{array}{l}\text { Problems interacting with } \\
\text { students (or their families) }\end{array}$ & $\begin{array}{l}\text { "I have limited communication } \\
\text { with my students" }\end{array}$ \\
\hline
\end{tabular}




\section{What other SUPPORT do you need to continue your teaching practice during COVID-19?}

\begin{tabular}{lll}
\hline Code & Description & Example \\
\hline Access & $\begin{array}{l}\text { Requests for adequate physical } \\
\text { infrastructure to enable the use of } \\
\text { online learning }\end{array}$ & $\begin{array}{l}\text { "I need a lot of support. I work in } \\
\text { a rural community that doesn't } \\
\text { even get free-to-air TV networks" }\end{array}$ \\
Development & $\begin{array}{l}\text { Opportunities for acquiring and } \\
\text { developing knowledge and skills } \\
\text { aimed at improving teaching } \\
\text { practices; it includes free and paid } \\
\text { courses and workshops }\end{array}$ & $\begin{array}{l}\text { "I would like to have access to } \\
\text { online courses [that enable me to } \\
\text { improve my teaching practice." }\end{array}$ \\
\hline
\end{tabular}

The researchers assigned participants a generic ID (P1, P2, P3, etc.) to maintain their anonymity. To exemplify findings, they translated sample comments from Spanish to English, focusing on substance over form. They used a word-by-word translation solely when doing so would convey the same or nearly the same meaning as the original message.

\section{Results}

Below we provide a summary of findings for each of the three key topic areas: 1) changes in teaching practice; 2) challenges; and 3) support needs.

\section{Changes in Teaching Practice}

Before the COVID-19 pandemic, all participants taught predominantly in face-to-face mode. Nearly half of them (49\%) did not use technologies, while $37 \%$ included some online components in their classes, such as requesting students to research information on the web. The remainder (13\%) had access to a virtual environment with educational contents or activities, such as a learning management system (LMS). The incorporation of online tools and related pedagogic strategies represented the most frequent change to their teaching practices during COVID-19: "My students and I have joined a virtual platform; we are learning from scratch how to work on it" [P56]. "[I have had] to create synchronous and asynchronous activities" [P49].

At the start of lockdown, 19\% of teachers had to suspend their practice at least temporarily. A third of the sample reported redesigning their courses, adapting contents and activities to ensure they are suitable in an online format. They used different strategies, such as uploading materials to an LMS (24\%), replacing face-to-face sessions with videoconferences (19\%), and using social media or messaging systems (most commonly WhatsApp) to keep in contact with their students or their families $(13 \%)$.

Some participants had to teach remotely without using digital technologies. They printed materials ("I print the materials every week and send them to my students" [P21]; 15\%) and called students on the phone (4\%). Two mentioned using the government's educational content. Teachers also combined strategies; for example: "I download the TV videos [from the national programme Aprende en Casa] and send them via WhatsApp and Facebook messenger. I also send [physical] 
workbooks to two students who are behind" [P3]. "I sought the best way to ensure my students could get physical, paper exercises, so they can keep doing their activities. I call them via their landline or mobile phones. Their moms help" [P6].

Teachers reported adapting learning activities to help students complete them independently. Some opted to make them more content-based: "I need to prepare more [contentbased] exercises to replace the interactive ones" [P40]. Others explicitly decided to "dumb them down": "Assignments have to be easier because students have to do them on their own" [P28]. They were concerned about this, as evidenced by their comments on students' progress (e.g., "students are not learning at all" [P8]; "this is a setback" [P34]).

\section{Challenges}

Most reported challenges relate to a deficient (or non-existent) infrastructure. The majority of teachers $(59 \%)$ have no broadband Internet access, and $20 \%$ can only get online using their mobile phone data, which is expensive. A few (5\%) have no Internet connection at home. Some lack electronic devices (e.g., "I have limited technological resources. If I had a laptop or tablet, I would have more teaching options" [P26]). Others have to cope with unreliable electricity services (e.g., "We have blackouts" [P47]).

Most participants reported that their students do not have an adequate Internet connection $(87 \%)$, electronic devices $(79 \%)$, or the required skills to learn online $(73 \%)$. Some teachers also struggle to cope with online education (e.g., "[I need to] learn to use digital tools and interact with students through [virtual] channels" [P55]). Communication is hindered. Teachers commented:

- "My students have no way of communicating with me from their communities" [P14].

- "I stopped teaching, as there are no resources in the community where I work. I have just sent assignments in a physical form. I have little contact with parents" [P58].

- "I cannot see my students daily, so I have to trust that they are doing everything on their own and learning" [P64].

This situation seemed to cause widespread negative sentiments: "Students feel uneasy; they don't understand the content; some parents are upset" [P20]. Some teachers try to be understanding (e.g., "[I need to be] patient when interacting with students who are used to participating in exclusively face-to-face classes" [P35]). Others worry about the implications:

- "The main challenge is to ensure that my students are not falling behind. As they are in a community away from technology, it is complex but not impossible. I hope they improve with the help of their moms" [P3].

- “[The challenge is] that students actually learn. I teach, but do they actually learn?" [P17].

- "I cannot tell if students are really understanding because I cannot see their faces" [P31].

One educator also reported concern about students' well-being: "My challenge is ensuring that my students understand the content in an autonomous manner, without feeling pressured or stressed. I would like them to have an enjoyable experience while learning" [P20]. Another one reflected on fairness: "[I want to] be fair when conducting assessments" [P23].

In line with this, $48 \%$ of teachers believed that the changes in their teaching practices had a negative impact on their students' progress, $40 \%$ thought the modifications were positive, and $12 \%$ were neutral. Respondents shared their perspectives and stories. For example: "This situation has left rural students unschooled. They do not have enough support to have a meaningful learning 
experience" [P8]. "Online classes are awesome, but I cannot have them with my students due to the rural context where they live. They do not have the economic and technological resources needed" [P29]. One participant concluded: "Distance education is not equal" [P4].

Changes in teaching practices represented increased workloads with "no time limit on workdays" [P50]. Teachers had to take on new tasks, including adaptation of content and activities. Some were asked to provide evidence of their work online. One explained it as follows: "Our immediate authorities are not supporting us. They want us to complete tasks that I consider irrelevant. They consider it urgent that we provide evidence that we are working, [...] regardless of the situation in which this work is happening" [P20].

Despite these challenges, most teachers (67\%) felt that this situation had strengthened their commitment as education professionals. They reported a willingness to experiment with new ways of teaching (73\%) and increased confidence in their capacity to teach online $(63 \%)$.

\section{Support Needs}

Teachers expressed a desire and determination to acquire both technical $(76 \%)$ and pedagogical competencies $(63 \%)$ to continue their practice at a distance. Three-quarters $(76 \%)$ took charge of their own learning, studying on their own and consulting online resources such as videos or blogs. Over a third (36\%) also participated in massive open online courses, or in other free webinars or workshops. A few (8\%) enrolled on a related academic degree programme (e.g., a master's degree in online learning). Most respondents (64\%) felt that the pandemic has had a positive impact on their professional development.

Stress was a common reaction (44\%), as was 'having ups and downs' (36\%). Only onefifth $(20 \%)$ felt predominantly calm or optimistic. Most teachers $(55 \%)$ felt that their institution lacked a clear plan: "I think we need a strategy to deliver activities in a physical form to students, and guidelines for parents" [P30]. Over a third (35\%) claimed they had no support from their educational centres. Table 3 summarises the institutional strategies available to address the changes in teaching practices during COVID-19.

\section{Table 3}

Institutional Support Available

\begin{tabular}{lll}
\hline Support strategy & Frequency $(\mathbf{n}=\mathbf{7 5})$ & Percentage \\
\hline $\begin{array}{l}\text { Clear guidance on how to deploy a teaching strategy } \\
\text { in the context of the pandemic }\end{array}$ & 23 & $31 \%$ \\
Online courses (interactive) & 23 & $31 \%$ \\
Online materials (non-interactive) & 21 & $28 \%$ \\
Community of educators & 14 & $19 \%$ \\
Individual support online & 8 & $11 \%$ \\
Free software licences & 3 & $4 \%$ \\
\hline
\end{tabular}

Note: Participants could select more than one answer option. 
In line with the reported changes and challenges, participants expressed that they and their students require access to the Internet and appropriate digital technologies:

- "[I wish] that all students had at least a TV and landline or a mobile phone, so we could keep working without internet access..." [P6]

- "[I need] better equipment because mine is obsolete" [P22]

- "[I need] my students to have internet access" [P62]

Formal training to acquire the required knowledge and skills to teach online was also a frequent request.

Finally, one educator emphasised the need for some understanding: "What I need is mostly moral support... and patience. We are teachers and human beings" [P64].

\section{Discussion}

The COVID-19 pandemic required academic institutions worldwide to engage in emergency remote teaching and increase their usage of online learning tools and approaches (Bao, 2020; Dube, 2020; Mohammed et al., 2020). While these strategies can facilitate continued access to education during lockdown, they also highlight the harsh reality that some communities face. This paper explores the challenges of, and changes in, teaching practices, and the support needed by rural teachers. Below, we summarise our findings and implications in terms of three areas: changes to teaching practices, teaching challenges, and teacher support needs.

\section{Changes to Teaching Practice}

Teachers whose students did not have a reliable Internet connection had to find different ways to continue their practice remotely. Some took advantage of the prevalence of mobile phones (INEGI, 2020) and used standard messaging services, mainly WhatsApp, to maintain communication with students or their parents. Others printed out materials and sent them to students. Others used the Mexican government's Aprende en Casa (Learn at Home) content, available on the Internet, television, and radio (SEP, 2020b). A few called students or their parents regularly on the phone to offer guidance, support, and instructions for activities.

To compensate for access and communication problems, teachers adapted learning materials and activities to cater to students' individual needs by making them more content based. In certain cases, the changes have translated into the simplification of activities ('dumbing down'), which risks lowering academic standards even further. Collaborative work was converted to independent study material on short notice to simplify delivery at a distance (Barton, 2020; World Bank, 2020). These changes responded to a practical need of ensuring students could move forward on their own.

These strategies enabled teachers to reach students through diverse and sometimes creative channels. They had to consider the needs and limitations of individual learners and customize their approach accordingly (e.g., sending videos to those who had access to a smartphone, and printing materials for those who did not have a connected device). When making phone calls, teachers increased the volume of their interactions with learners or their parents. This had time and financial costs; it is unlikely that their educational institutions covered their higher phone bills. In line with reports from telesecundaria, some teachers lent their own devices to students (Ramos Ramón \& Frías López, 2019). Such practices show the commitment of some rural teachers to support student 
learning. They also highlight the value of shifting the focus from "edtech" as the solution to ensure continued access to education by key people who work to support their communities in contextsensitive ways.

The loss of the scaffold provided by synchronous teacher guidance could lead to potentially different outcomes. First, in the context of learners' limited digital literacy (Ramos Ramón \& Frías López, 2019) and generally poor academic performance (OECD, 2019), this absence of teaching presence may be deeply discouraging to students and result in disengagement. Such disengagement would represent a tragedy for rural communities that had high dropout rates (INEE, 2019; Wells et al., 2019) even before COVID-19. Alternatively, personalised communication (e.g., phone calls) may be enough to compensate for a scaled-back academic experience. Some learners could benefit by using this opportunity to develop their autonomy and deepen their resilience. Future research could focus on exploring these potential outcomes.

\section{Teaching Challenges}

As has been reported extensively (Çiftçi \& Cin, 2018; Dube, 2020; Kapasia et al., 2020; Mohmmed et al., 2020; Omodan, 2020; Sintema, 2020), rural teachers faced distinct challenges during COVID-19, most of which existed before the onset of the pandemic. Figure 1 shows how these challenges interconnected for teachers in our study. First, poverty contributed to these areas' inadequate infrastructure, including limited access to electricity, Internet connection and electronic devices for both teachers and students. For example, as noted earlier, the Mexican government had considered it economically unfeasible to properly equip educational centres in small rural areas (INEE, 2006, p. 78). This inadequate infrastructure results in limited digital literacy for both teachers and students as well as restricted opportunities for communication among and between them (Bao, 2020; Trust \& Whalen, 2020).

\section{Figure 1.}

Challenges Faced by Teachers and Students in Rural Communities During COVID-19

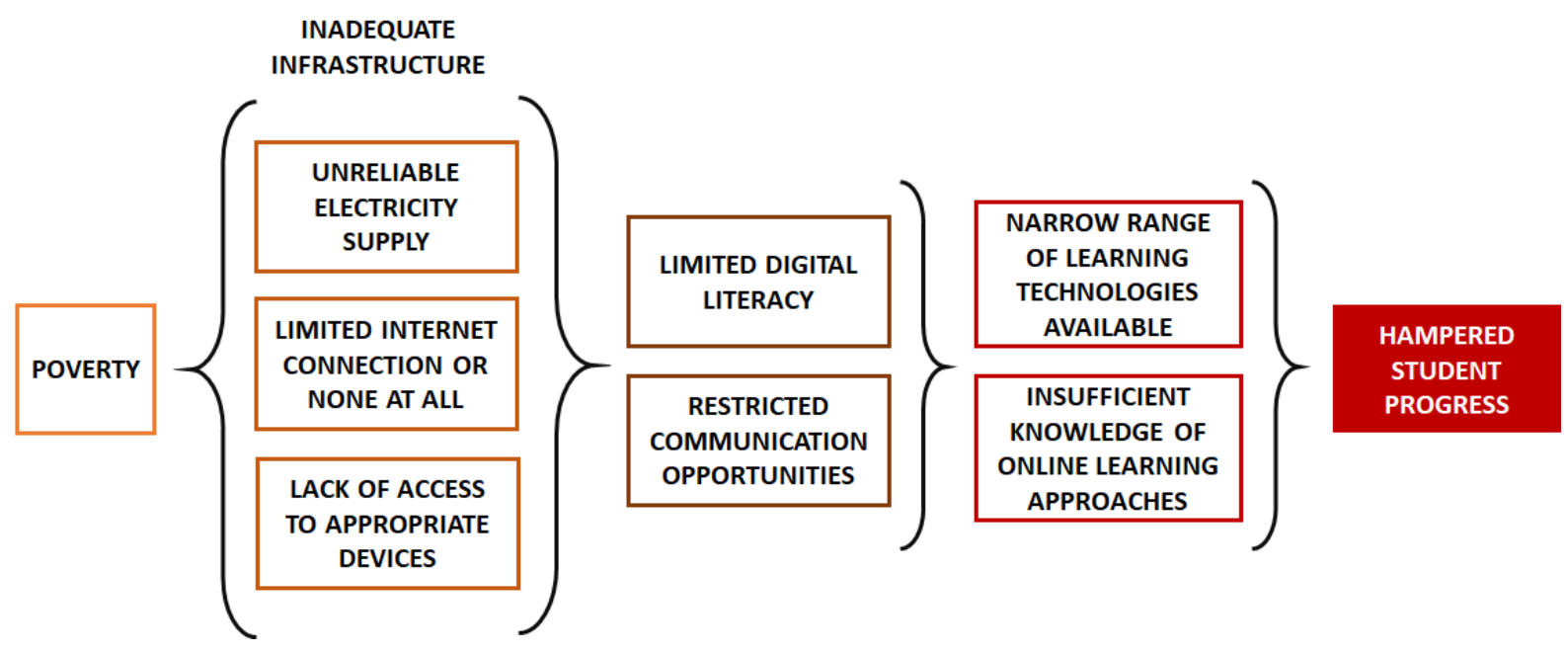


For rural teachers, limited digital literacy and a lack of connection to their counterparts in better connected parts of the country resulted in a lack of training to teach remotely (Trust \& Whalen, 2020), the absence of pedagogic design of activities and content (Barton, 2020), and little information or planning in terms of emergency remote teaching (Hodges et al., 2020). Finally, the narrow range of learning technologies available and the insufficient knowledge of online learning approaches hampered progress. However, these observations raise a set of more basic questions. If a community has an unreliable electricity supply, how can schools and universities plan appropriate professional development opportunities for teachers to learn how to teach online? Should we focus on providing students and teachers with access to devices and connectivity when they may have no suitable environments to work remotely from home?

In the past, student problems, such as few and low-quality resources (Juárez Bolaños \& Rodríguez Solera, 2016), could be addressed through face-to-face interactions. While resource scarcity has not improved, teachers' power to address student problems has been attenuated. Rural teachers in our study believed that changes in their teaching practices have had a negative impact on students' progress. The implication is that those who are behind will be disadvantaged further, which widens the learning gaps among students. These challenges are mostly defined by the perspective of external observers or national educational norms.

Despite this apparently grim scenario, most respondents could also identify benefits derived from the pandemic. They reported having a strengthened commitment to their job, willingness to experiment with new ways of teaching, and confidence in their own capacity. Their views match their reported practices that focus on students as individuals. For example, in a traditional setting, it would not be expected for teachers to call learners on the phone regularly. Lockdown conditions make this the only feasible way of maintaining communication with some students. As in Ramos Ramón and Frías López (2019), this points to teachers' resilience and commitment to supporting learners. Empowering teachers to explore, direct, refine, and support learning could potentially yield better outcomes than focusing on a tech-based strategy.

\section{Teacher Needs for Support}

Ideally, teachers should have an array of on-the-job learning opportunities and related guidelines to engage in online education (Omodan, 2020; World Bank, 2020). In practice, this is not always the case (Trust \& Whalen, 2020), particularly for rural teachers (Hallinger \& Liu, 2016). Having no clear institutional plan to deploy a teaching strategy in the context of COVID19 and sometimes no support at all, most respondents turned to independent learning to acquire the technical and pedagogical knowledge and skills they needed to continue their practice remotely. They accessed online resources or joined courses to plug these gaps. Six went as far as deciding to enrol in an academic degree programme to be better prepared to teach online or use learning technologies.

By taking charge of their own professional development, teachers show their resourcefulness (Ramos Ramón \& Frías López, 2019). However, there is only so much they can do without support. Stress and mood changes, potentially leading to depression (Soria-Saucedo et al., 2018), were common reactions. Rural teachers need the basic infrastructure, but also formal, timely, and relevant professional development opportunities. In the absence of these opportunities, teachers, as well as their students, may find themselves at a significant disadvantage.

A national effort, an action plan, and an investment strategy to support rural communities are needed in Mexico. This structured approach should take into account the local environment, as 
has been requested by local teachers (CNTE Section XXII, 2020). It should aim to reduce the gap between advantaged and disadvantaged groups. As it stands, online learning excludes those in deprived contexts, favouring urban learners (Dube, 2020; Omodan, 2020; Traxler et al., in press; World Bank, 2020). There is a general risk that as the international community mobilises to strengthen school systems, rural communities will be further disadvantaged. A context-sensitive approach (Çiftçi \& Cin, 2018; Traxler et al., in press) should consider the needs, expectations, requirements, and hardships of the community it aims to serve.

\section{Conclusion}

In many contexts, online learning represents a solution that facilitates flexibility and continuity. However, its use during the COVID-19 pandemic also shows how the digital divide has widened, amplifying the disadvantages suffered by some rural communities. By focusing on the incorporation of digital technologies as the main way to ensure access to education, governments and policymakers are creating a frustrating situation for many rural educators who have little or no access to the basic infrastructure they need. Deficient Internet connections and lack of electronic devices are salient causes for concern.

Governments, policymakers, and institutional authorities should address the challenges of rural communities by providing a context-sensitive approach. Measures that help the (often urban) majority might exclude rural minorities. Resources and priorities should shift away from merely edtech and its associated dedicated content, training, and infrastructure, towards empowering people. This approach could include informal leaders, who might play a role in exploring, directing, refining, and supporting learning, in such a way that this effort and its outcomes are valued by the community.

The limitations of this study included the composition and size of it sample. It is likely that those in the most disadvantaged settings (e.g., without electricity) were not reached. Moreover, within rural communities, there are people at risk of being further disadvantaged, such as those belonging to indigenous groups, those who speak different languages and those who have cultural backgrounds that differ from the dominant Mexican majority. Future studies could focus on those hardest to reach as well as the role of culture, family, and community support in the context of education during and potentially after COVID-19.

\section{Acknowledgements}

The authors thank Ana Cecilia Montoya Contreras for her help with the coding and translating of comments, and Marisol Salazar Márquez and Daniela María García García for their help contacting potential participants. 


\section{References}

Ávila, J. L. (2012). Población y desarrollo rural en México [Population and rural development in Mexico]. Comité Especial de Población y Desarrollo de la Comisión Económica para América Latina. https://www.cepal.org/sites/default/files/presentations/5-2joseluisavila_0.pdf

Bao, W. (2020). COVID-19 and online teaching in higher education: A case study of Peking University. Human Behavior and Emerging Technologies, 2(2), 113-115. https://doi.org/10.1002/hbe2.191

Barton, D. C. (2020). Impacts of the COVID-19 pandemic on field instruction and remote teaching alternatives: Results from a survey of instructors. Ecology and Evolution, 1-9. https://doi.org/10.1002/ece3.6628

Çiftçi, Ş. K., \& Cin, F. M. (2018). What matters for rural teachers and communities? Educational challenges in rural Turkey. Compare: A Journal of Comparative and International Education, 48(5), 686-701. https://doi.org/10.1080/03057925.2017.1340150

Consejo Nacional de Población (Conapo). (2016). Índice de marginación por entidad federativa y municipio 2015 [Marginalisation index by federal entity and municipality 2015]. https://www.gob.mx/conapo/documentos/indice-de-marginacion-por-entidad-federativa-ymunicipio-2015

Coordinación General @prende.mx. (2020).La Telesecundaria celebra su 52 aniversario [Telesecundaria celebrates its 52nd anniversary]. Gobierno de México. https:/www.gob.mx/aprendemx/articulos/la-telesecundaria-celebra-su-52aniversario?idiom $=\mathrm{es}$

Coordinadora Nacional de Trabajadores de la Educación (CNTE) Sección XXII. (2020). Aprende en Casa no garantiza el acceso a educación sin internet y electricidad en México [Learn from Home does not guarantee access to education without internet and electricity in Mexico]. https://www.cencos22oaxaca.org/boletines-informativos/aprende-en-casa-no-garantiza-elacceso-a-educacion-sin-internet-y-electricidad-en-mexico/

Dube, B. (2020). Rural Online Learning in the Context of COVID-19 in South Africa: Evoking an Inclusive Education Approach. Multidisciplinary Journal of Educational Research, 10(2), 135-157. http://dx.doi.org/10.447/remie.2020.5607

Hallinger, P., \& Liu, S. (2016). Leadership and teacher learning in urban and rural schools in China: Meeting the dual challenges of equity and effectiveness. International Journal of Educational Development, 51, 163-173. https://doi.org/10.1016/j.ijedudev.2016.10.001

Hodges, C., Moore, S., Lockee, B., Trust, T., \& Bond, A. (2020). The Difference Between Emergency Remote Teaching and Online Learning. Educause. https://er.educause.edu/articles/2020/3/the-difference-between-emergency-remote-teachingand-online-learning https://doi.org/10.1002/hbe2.191 https://www.researchgate.net/publication/340332893

Instituto Nacional de Estadística, Geografía e Informática (INEGI). (2020). Comunicado de Prensa Núm. 103/20. Encuesta nacional sobre disponibilidad y uso de tecnologías de la información en los hogares, 2019 [Press Release 103/20. National survey on the availability and usage of information technologies at home, 2019]. https://www.inegi.org.mx/contenidos/saladeprensa/boletines/2020/OtrTemEcon/ENDUTIH_ 2019.pdf 
Instituto Nacional para la Evaluación de la Educación (INEE). (2006). Panorama educativo de México. Indicadores del Sistema Educativo Nacional 2006 [Educational Scenario in Mexico. Indicators of the National Educational System 2006]. https://historico.mejoredu.gob.mx/wpcontent/uploads/2018/12/P1B104.pdf

Instituto Nacional para la Evaluación de la Educación (INEE). (2019). Panorama educativo de México [Educational Scenario in Mexico]. https://www.inee.edu.mx/wpcontent/uploads/2019/08/P1B117.pdf

Juárez Bolaños, D., \& Rodríguez Solera, C. R. (2016). Factors that affect educational equity in rural schools in Mexico. Pensamiento Educativo. Revista de Investigación Educacional Latinoamericana, 53(2), 1-15. https://doi.org/10.7764/PEL.53.2.2016.8

Kapasia, N., Paul, P., Roy, A., Saha, J., Zaveri, A., Mallick, R., Barman, B., Das, P., \& Chouhan, P. (2020). Impact of lockdown on learning status of undergraduate and postgraduate students during COVID-19 pandemic in West Bengal, India. Children and Youth Services Review, 116. https://doi.org/10.1016/j.childyouth.2020.105194

Martin, F., Budhrani, K., \& Wang, C. (2019). Examining faculty perception of their readiness to teach online. Online Learning, 23(3), 97-119. http://dx.doi.org/10.24059/olj.v23i3.1555

Mohmmed, A. O., Khidhir, B. A., Nazeer, A., \& Vijayan, V. J. (2020). Emergency remote teaching during Coronavirus pandemic: the current trend and future directive at Middle East College Oman. Innovative Infrastructure Solutions, 5. https://doi.org/10.1007/s41062-020-00326-7

Omodan, B. I. (2020). The vindication of decoloniality and the reality of COVID-19 as an emergency of unknown in rural universities. International Journal of Sociology of Education, 1-26. http://doi.org/10.17583/rise.2020.5495

Organisation for Economic Co-operation and Development (OECD). (2007). Estudios de Política Rural. México [Rural Policy Reviews. Mexico]. https://www.oecd.org/centrodemexico/medios/39076610.pdf

Organisation for Economic Co-operation and Development (OECD). (2019). Programme for International Student Assessment (PISA). Mexico. Results from PISA 2018. https://www.oecd.org/pisa/publications/PISA2018_CN_MEX.pdf

Ramos Ramón, M. C., \& Frías López, A. K. (2019). Representaciones sociales sobre el uso de las TIC por docentes de telesecundaria en Tabasco, México [Social representations on the use of ICT by telesecundaria teachers in Tabasco, Mexico]. Emerging Trends in Education, 1(2), 28-46. https://doi.org/10.19136/etie.a1n2.2992

Salkind, N. J. (2010). Triangulation. In Encyclopedia of Research Design. SAGE Publications, Inc. https://dx.doi.org/10.4135/9781412961288.n469

Secretaría de Educación Pública (SEP). (2016). Propuesta curricular para la educación obligatoria 2016 [Curricular proposal for mandatory education 2016]. https://www.gob.mx/cms/uploads/docs/Propuesta-Curricular-baja.pdf

Secretaría de Educación Pública (SEP). (2020a). Boletín No. 102 Inicia SEP estrategia radiofónica para comunidades indigenas del programa Aprende en Casa [Newsletter \#102 SEP starts the radio strategy for indigenous communities with the Learn at Home programme]. https://www.gob.mx/sep/articulos/boletin-no-102-inicia-sep-estrategia-radiofonica-paracomunidades-indigenas-del-programa-aprende-en-casa?idiom=es 
Secretaría de Educación Pública (SEP). (2020b). Boletín No. 223 Presenta SEP programación y horarios del programa de Educación a Distancia Aprende en Casa II [Newsletter \#223 SEP introduces the schedule of the distance education programme Learn at Home II]. https://www.gob.mx/sep/articulos/boletin-no-223-presenta-sep-programacion-y-horarios-delprograma-de-educacion-a-distancia-aprende-en-casa-ii?idiom=es

Sintema, E. J. (2020). Effect of COVID-19 on the performance of grade 12 students: Implications for STEM education. Eurasia Journal of Mathematics, Science and Technology Education, 16(7), em1851. https://doi.org/10.29333/ejmste/7893

Soria-Saucedo, R., Lopez-Ridaura, R., Lajous, M., \& Wirtz, V. J. (2018). The prevalence and correlates of severe depression in a cohort of Mexican teachers. Journal of Affective Disorders, 234, 109-116. https://doi.org/10.1016/j.jad.2018.02.036

Traxler, J., Smith, M., Scott, H., \& Hayes, S. (in press). Learning through the crisis. Edtech Hub policy brief.

Trust, T. \& Whalen, J. (2020). Should teachers be trained in emergency remote teaching? Lessons learned from the COVID-19 pandemic. Journal of Technology and Teacher Education, 28(2), 189-199. https://www.learntechlib.org/primary/p/215995/

Wells, R., Manly, C. A., Kommers, S., \& Kimball, E. (2019). Narrowed gaps and persistent challenges: examining rural-nonrural disparities in postsecondary outcomes over time. American Journal of Education, 126(1), 1-31. https://doi.org/10.1086/705498

World Bank. (2020). Rapid response briefing note: Remote Learning \& COVID-19 Outbreak. http://documents1.worldbank.org/curated/en/266811584657843186/pdf/Rapid-ResponseBriefing-Note-Remote-Learning-and-COVID-19-Outbreak.pdf 